\title{
Performance of Automated Chemiluminescence Assay for Antiphospholipid Antibody Testing
}

\author{
Shuhua Li, Jae-Lim \\ Choi, Bo-Ram Kim, \\ Cheol-Soo Kang, Ri- \\ Young Goh, Kwang- \\ Sook Woo, and Jin- \\ Yeong Han \\ Department of Laboratory \\ Medicine, Dong-A \\ University Medical Center, \\ Busan, Korea
}

\section{Corresponding author:} Jin-Yeong Han

Department of Laboratory Medicine, Dong-A University College of Medicine, 32 Daesingongwon-ro, Seo-gu, Busan 49201, Korea Tel: $+82-51-240-5323$

Fax: +82-51-255-9366

E-mail: jyhan@dau.ac.kr

pISSN: 2384-2458

elSSN: 2288-7261

\begin{abstract}
Background: Detection of antiphospholipid antibodies (aPL) can be considered problematic due to assay variability and reagent sensitivity, high false-positive and false-negative rates, and lack of assay standardization. Therefore, utilizing an automated system can improve reproducibility and reduce interlaboratory variation. Here, we evaluated the analytical performance of the new automated ACL AcuStar chemiluminescence assay (Instrumentation Laboratory, USA). This was compared to the results of a panel analyzed with the QUANTA Lite ELISA (INOVA Diagnostics Inc., USA).

Methods: We evaluated the inter-assay precision, linearity, and carry-over between the two methods, ACL and ELISA. A reference range study for each of the anticardiolipin (aCL) and anti- $\beta_{2}$ glycoprotein-I (a $\beta_{2}$ GPI) IgG and IgM antibodies were performed using 135 healthy patient samples, which served as controls. We then compared the accuracy among the AcuStar and ELISA systems via four aPL tests. For this comparison, 69 patient samples suspected of an autoimmune disorder were used as the experimental panel.

Results: The AcuStar analyzer showed excellent precision, linearity, and carry-over for all four assays. The calculated cutoff values were $20.3 \mathrm{U} / \mathrm{mL}$ for aCL IgG, $20.3 \mathrm{U} / \mathrm{mL}$ for aCL IgM, 26.3 U/mL for a $\beta_{2}$ GPI IgG, and $11.9 \mathrm{U} / \mathrm{mL}$ for a $\beta_{2}$ GPI IgM. The consensus between AcuStar and ELISA results were generally comparable. Total agreement varied between $82.6 \%$ and $95.7 \%$, and kappa values showed moderate to good agreement.

Conclusions: Our study demonstrates that the new AcuStar chemiluminescence assay showed better performance. This automated system leads to improved reproducibility and reduces interlaboratory variability.
\end{abstract}

(J Lab Med Qual Assur 2015;37:134-140)

Key Words: Antiphospholipid syndrome, Anticardiolipin antibodies, Anti- $\beta_{2}$ glycoprotein-I antibody, Automation, Chemiluminescence assay

Received March 9, 2015, Revision received June 4, 2015, Accepted June 4, 2015

\section{INTRODUCTION}

Antiphospholipid syndrome (APS) is an autoimmune condition characterized by arterial or venous thrombosis and/or pregnancy complications due to the persistent presence of antiphospholipid antibodies (aPL). These aPL are naturally occurring heterogeneous autoantibodies that bind to phospholipid-bound proteins [1-3]. aPL associated with APS includes lupus anticoagulant (LA), anticardiolipin ( $\mathrm{aCL}$ ), and anti- $\beta_{2}$ glycoprotein-I ( $\left.\beta_{2} \mathrm{GPI}\right)$
IgG or IgM antibodies.

To make a conclusive diagnosis of APS, at least one of the clinical and laboratory criteria need to be met [4,5]. Laboratory abnormality must be present on two or more occasions and at least 12 weeks apart. Systematic reviews have reported that LA is a stronger risk factor for both thrombosis and obstetric complications compared to aCL or $\mathrm{a}_{2} \mathrm{GPI}$ antibodies [1-5]. However, three aPL have now been associated with the highest risk for thrombosis and so can be implemented in laboratory criteria for APS [1- 


\title{
Journal of LABORATORY MEDICINE and QUALITY ASSURANCE
}

\author{
Shuhua Li et al • Automated Antiphospholipid Antibody Test
}

5]. Thus, evaluation of patients using aPL profile rather than a separate test may be more useful in assessing thrombotic risk.

The laboratory identification of aPL can be problematic because the available tests have sensitivity and specificity variability, poor reproducibility, and a lack of standardization [6-9]. Currently, aCL and $\mathrm{a} \beta_{2}$ GPI antibodies have been detected by an ELISA; however, recently developed automated platforms have been introduced [10-12]. The introduction of an automated system can improve reproducibility and reduce interlaboratory variation. In this study, we evaluated the analytical performance of a new automated chemiluminescence assay (HemosIL ACL AcuStar aPL assay; Instrumentation Laboratory, Bedford, MA, USA) and compared the results of a panel (aCL IgG, aCL IgM, $a \beta_{2}$ GPI IgG, and $a \beta_{2}$ GPI IgM) with the currently available ELISAs.

\section{MATERIALS AND METHODS}

\section{Samples}

We included samples from 69 patients, who were referred for the evaluation of autoimmune disorders such as systemic lupus erythematosus (SLE) or rheumatoid arthritis, hypercoagulability, and cardiovascular diseases. Venous blood samples were collected in serum separation tubes, VACUETTE (Greiner Bio-One $\mathrm{GmbH}$, Kremsmunster, Austria) and the obtained serum samples after centrifugation were stored at $-80^{\circ} \mathrm{C}$ for further analysis. Samples from the 135 healthy controls (65 women and 73 men; age, 43.8 \pm 11.1 years) were also collected for the calculation of reference ranges. Informed consents were obtained from all patients prior to the study.

\section{Antiphospholipid Antibody Assays}

The HemosIL AcuStar aPL assay uses a two-step immunoassay method based on chemiluminescence technology. The assay panel includes aCL IgG, aCL IgM, $\mathrm{a} \beta_{2}$ GPI IgG, and $a \beta_{2}$ GPI IgM. Magnetic particles are coated with cardiolipin complexed with human $\beta_{2} \mathrm{GPI}$ in
aCL antibody test, and human $\beta_{2}$ GPI alone in $a \beta_{2}$ GPI antibody test. These antigen-coated magnetic particles capture the corresponding aPL IgG and/or IgM in the samples. An isoluminol-labeled secondary antibody in the tracer then binds to the captured antibodies, resulting in an emission of light proportionate to the concentration of the antibodies. The emitted light is measured in relative light units, and all aPL assays are standardized to a cutoff of $20 \mathrm{U} / \mathrm{mL}$.

ELISA of aCL and $\mathrm{a}_{2} \mathrm{GPI}$ antibodies was performed using the QUANTA Lite ACA and $\beta_{2}$ GPI kit (INOVA Diagnostics Inc., San Diego, CA, USA) according to the manufacturer's instructions. Polystyrene microwell plates are coated with purified cardiolipin antigen complexed with bovine $\beta_{2}$ GPI in aCL antibody assay, and purified $\beta_{2} \mathrm{GPI}$ antigen alone in $\mathrm{a}_{2} \mathrm{GPI}$ antibody test. Optical absorbance was measured on a Microplate Reader Model 680 (Bio-Rad Laboratories, Hercules, CA, USA). Test results were expressed semi-quantitatively in standard units, and the cutoff value for the positive results was assigned to $>20$ units for all aPL tests.

\section{Evaluation of Analytical Performance Evaluation}

Inter-assay precision was assessed using the low and high control materials according to the Clinical and Laboratory Standards Institute (EP05-A2) [13]. Each control was analyzed in duplicate for 5 days with two runs a day. Linearity study of dilution recovery was performed using clinical samples according to CLSI EP06-A 〔14〕. Two serum samples with concentrations within $\pm 10 \%$ of the upper limit of analytical measurement range (AMR) and within $\pm 50 \%$ of the lower limit of AMR were proportionately mixed and tested in duplicates. We also evaluated percent carry-over using one normal and one high abnormal sample. A reference range study, for each of AcuStar aPL tests, was performed using 135 healthy control samples according to CLSI EP28-A3c [15]. The cutoff values of our laboratory were assigned at the 99th percentile. We compared the results for aCL and $a \beta_{2} \mathrm{GPI}$ IgG and IgM obtained with AcuStar and ELISA in 69 samples in accordance with CLSI EP09-A2 [16]. The agreement percentages and Cohen's kappa values were 


\section{Journal of LABORATORY MEDICINE and QUALITY ASSURANCE}

\section{Shuhua Li et al • Automated Antiphospholipid Antibody Test}

calculated.

\section{Statistical Analysis}

Statistical analysis was performed using the MedCalc Software ver. 9.3 (MedCalc Software bvba, Ostend, Belgium) and EP Evaluator Release 10 (Data Innovations LLC, South Burlington, VT, USA). We also used Microsoft Office Excel 2007 (Microsoft Co., Redmond, WA, USA). A $P$-value $<0.05$ was considered as significantly different.

\section{RESULTS}

\section{Precision, Linearity, and Carry-Over}

The AcuStar aPL assay panel was evaluated for several analytical performance characteristics including precision, linearity, and carry-over. Table 1 shows within run and total \% CV at low and high concentration levels. AcuStar assays demonstrated within run and total $\mathrm{CV}$ of $<7.0 \%$ and $<9.0 \%$, respectively. The AcuStar analyzer showed excellent linearity for all four assays evaluated, within the

Table 1. Within run and total CV of the AcuStar assay

\begin{tabular}{lcccc}
\hline & $\begin{array}{c}\mathrm{aCL} \\
\text { IgG }\end{array}$ & $\begin{array}{c}\mathrm{aCL} \\
\mathrm{IgM}\end{array}$ & $\begin{array}{c}\mathrm{a} \beta_{2} \mathrm{GPI} \\
\mathrm{IgG}\end{array}$ & $\begin{array}{c}\mathrm{a} \beta_{2} \mathrm{GPI} \\
\mathrm{IgM}\end{array}$ \\
\hline $\begin{array}{l}\text { Low control } \\
\quad \text { Within run \% CV }\end{array}$ & 6.2 & 2.9 & 6.4 & 5.3 \\
$\quad$ Total \% CV & 8.6 & 3.0 & 7.7 & 5.6 \\
$\begin{array}{l}\text { High control } \\
\quad\end{array}$ & & & & \\
$\quad$ Within run \% CV & 4.3 & 1.8 & 6.6 & 6.0 \\
$\quad$ Total \% CV & 6.1 & 2.5 & 7.0 & 6.5 \\
\hline
\end{tabular}

Abbreviations: aCL, anticardiolipin antibodies; $a \beta_{2} \mathrm{GPI}$, anti- $\beta_{2}$ glycoprotein-I antibodies. allowable systemic errors of $10.0 \%$ (1.7\% to $4.5 \%$ ). The AMR specified by the manufacturer was 2.6-2,024 $\mathrm{U} / \mathrm{mL}$ for aCL IgG, $1.0-774 \mathrm{U} / \mathrm{mL}$ for aCL IgM, 6.46,100 U/mL for $\mathrm{a} \beta_{2} \mathrm{GPI}$ IgG, and $1.1-841 \mathrm{U} / \mathrm{mL}$ for $\mathrm{a} \beta_{2} \mathrm{GPI}$ IgM, while reportable ranges validated in this study were 2.6-40,480 U/mL, 1.0 - 15,480 U/mL, 6.4-122,000 U/mL, and $1.1-16,820 \mathrm{U} / \mathrm{mL}$, respectively. The carry-over was also all within $\pm 1.0 \%$ (-0.8\% to $0.2 \%$ ).

\section{Reference Ranges}

The upper reference limits were calculated within the 99th percentile of the 135 healthy control values. The cutoff value of the manufacturer is $20 \mathrm{U} / \mathrm{mL}$, whereas calculated cutoff values of AcuStar assays were 20.3 $\mathrm{U} / \mathrm{mL}$ for aCL IgG, $20.3 \mathrm{U} / \mathrm{mL}$ for aCL IgM, $26.3 \mathrm{U} /$ $\mathrm{mL}$ for $\mathrm{a} \beta_{2}$ GPI IgG, and $11.9 \mathrm{U} / \mathrm{mL}$ for $\mathrm{a} \beta_{2} \mathrm{GPI} \operatorname{IgM}$, respectively.

\section{Method Comparison with ELISA}

Patient samples in the AcuStar assay were analyzed with two different cutoffs, our laboratory's as well as the manufacturer's cutoffs. For the ELISA, the manufacturer' s cutoffs were applied. With the our laboratory's cutoffs, $3(4.3 \%)$ aCL IgG, 9 (13.0\%) aCL IgM, $3(4.3 \%)$ a $\beta_{2}$ GPI IgG, and $10(14.5 \%)$ a $\beta_{2}$ GPI IgM results were positive in the AcuStar assay. The ELISA resulted in $6(8.7 \%)$ aCL IgG, $13(18.8 \%)$ aCL IgM, $9(13.0 \%)$ a $\beta_{2}$ GPI IgG, and 11 (15.9\%) a $\beta_{2}$ GPI IgM positive results. Thirty discordant results were observed between the two methods, 3 aCL IgG (only ELISA positive), 12 aCL IgM (8 ELISA alone and 4 AcuStar alone positive), 6 a $\beta_{2}$ GPI IgG (only ELISA positive), and $9 \mathrm{a} \beta_{2}$ GPI IgM (5 ELISA alone and

Table 2. Percentage agreement and kappa values (95\% confidence interval) of the AcuStar assay

\begin{tabular}{ccccc}
\hline & aCL IgG & aCL IgM & $\mathrm{a} \beta_{2}$ GPI IgG & a $\beta_{2}$ GPI IgM \\
\hline In-house cutoffs & & & & \\
Agreement (\%) & $95.7(88.0-98.5)$ & $82.6(72.0-89.8)$ & $91.3(82.3-96.0)$ & $87.0(77.0-93.0)$ \\
$\quad$ Kappa value & $0.65(0.26-1.04)$ & $0.36(0.02-0.69)$ & $0.47(0.06-0.87)$ & $0.50(0.19-0.80)$ \\
Manufacturer's cutoffs & & & & \\
Agreement (\%) & $95.7(88.0-98.5)$ & $82.6(72.0-89.8)$ & $88.4(78.8-94.0)$ & $91.3(82.3-96.0)$ \\
Kappa value & $0.65(0.26-1.03)$ & $0.36(0.02-0.69)$ & $0.37(0.00-0.78)$ & $0.62(0.33-0.91)$ \\
\hline
\end{tabular}

Abbreviations: aCL, anticardiolipin antibodies; $a \beta_{2}$ GPI, anti- $\beta_{2}$ glycoprotein-I antibodies. 


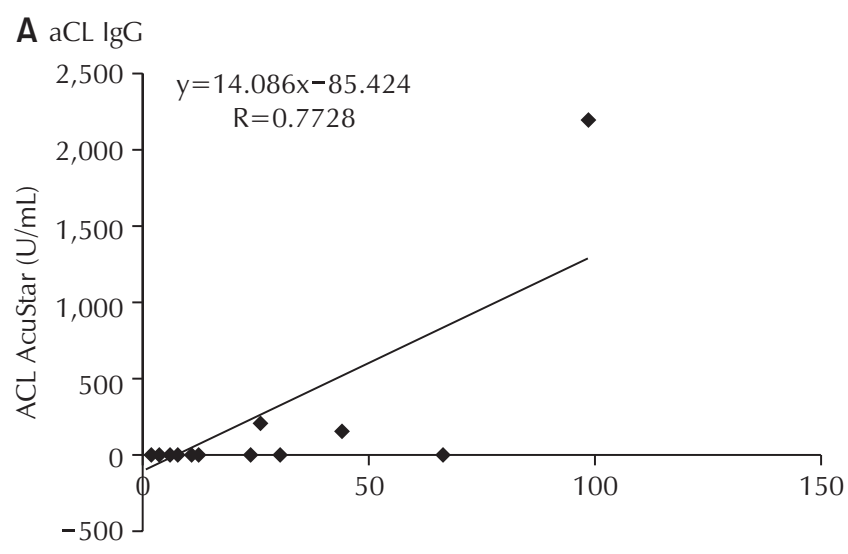

INOVA ELISA (GPL)

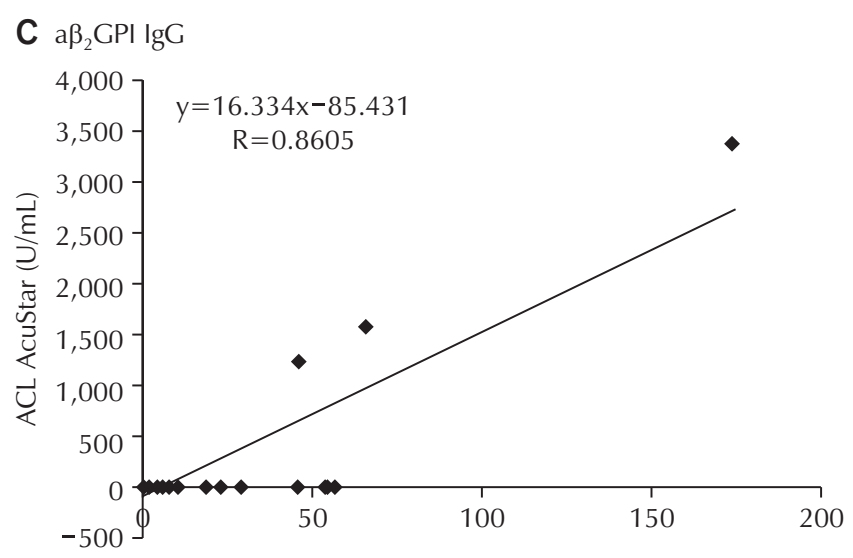

INOVA ELISA (SGU)
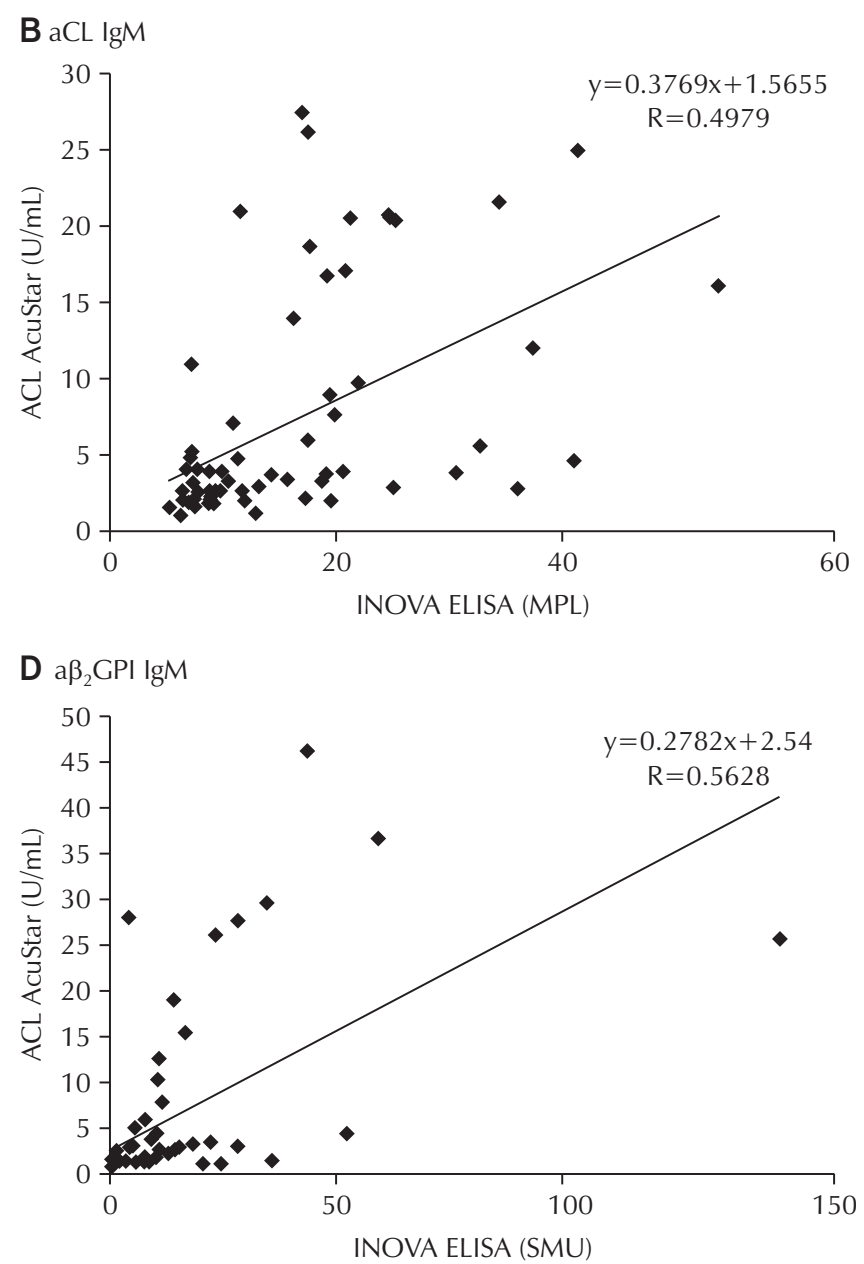

Fig. 1. Comparison between the AcuStar assay and ELISA for (A, B) aCL and (C, D) a $\beta_{2} G P I$ (IgG and IgM). Abbreviations: aCL, anticardiolipin antibodies; $a \beta_{2}$ GPI, anti- $\beta_{2}$ glycoprotein-I antibodies; GPL, IgG anticardiolipin units; MPL, IgM anticardiolipin units; SGU, IgG a $\beta_{2}$ GPI units; SMU, IgM a $\beta_{2}$ GPI units.

4 AcuStar alone positive) tests, respectively. Table 2 shows the analytical agreement of the AcuStar aPL assay panel compared with the ELISA. Total agreement varied between $82.6 \%$ and $95.7 \%$, and kappa values showed fair to good agreement.

Using the manufacturer's cutoffs, 3 (4.3\%) aCL IgG, 9 (13.0\%) aCL IgM, 5 (7.2\%) a $\beta_{2}$ GPI IgG, and 7 (10.1\%) $\mathrm{a} \beta_{2} \mathrm{GPI}$ IgM results were positive in the AcuStar assay. Discordant results in aCL IgG and IgM were the same in our laboratory's cutoffs, and differed only in $a \beta_{2}$ GPI IgG (6 ELISA alone and 2 AcuStar alone positive) and $a \beta_{2} \mathrm{GPI}$ IgM (5 ELISA alone and 1 AcuStar alone positive). However, the analytical agreement and kappa statistics were comparable between the two different cutoffs.
We also compared the numerical test results between AcuStar and ELISA using a Pearson correlation coefficient. In Fig. 1, all assays showed significant correlation determined by correlation coefficient $r$ values $(P<0.0001)$. Between AcuStar and ELISA, both aCL and $\mathrm{a} \beta_{2} \mathrm{GPI}$ showed better correlation for IgG than for IgM.

\section{DISCUSSION}

APS is a heterogeneous autoimmune disorder characterized by a wide range of clinical features, primarily thrombotic or obstetric complications. These clinical manifestations lack specificity. Therefore, a defining feature of APS is persistent aPL, being able to identify 


\section{Journal of LABORATORY MEDICINE and QUALITY ASSURANCE}

\section{Shuhua Li et al • Automated Antiphospholipid Antibody Test}

these circulating antibodies is a necessity for correct diagnosis $[5-9,17]$.

The laboratory detection of aPL can be problematic due to poor assay reproducibility and the lack of standardization. In relation to these issues, guidelines for laboratory identification of aPL have been published and updated by international working groups $[4-6,8]$. Recommendations covering the contributing factors include standards, calibration, and assay-specific. Application of these guidelines can help in implementing the best practices and the standardization of the assays.

Besides conventional ELISA, new platforms and detection technologies have been introduced [10-12,18-22]. The new automated platforms are expected to improve reproducibility and reduce interlaboratory variation.

AcuStar assays demonstrated within run and total CV of $<7.0 \%$ and $<9.0 \%$, respectively. Precision is an important requirement, especially for automated analyzers; therefore, a between run imprecision of $<10 \%$ is recommended $[5,6,8,9,17]$. The AcuStar analyzer showed excellent linearity for all four assays evaluated, within the allowed systemic error of $10.0 \%$ (1.7\% to $4.5 \%)$. The carry-over was all within $\pm 1.0 \%$ ( $-0.8 \%$ to $0.2 \%)$. The AcuStar allowed for a more broad reportable range for all four aPL assays compared to the ELISA studies. If testing automatically extended in automated re-dilution, 20 times of the cutoff could be obtained as compared to 6 to 10 times their respective cutoff values in currently available ELISAs [11].

According to the guidelines, it is recommended that laboratories determine their own in-house cutoff values by the 99th percentile of a healthy population of at least 120 healthy patient samples. In our study, calculated cutoffs were close to those of the manufacturer and only differed for $a \beta_{2}$ GPI IgM (11.9 U/mL versus $20 \mathrm{U} / \mathrm{mL}$, respectively). Van Hoecke et al. [18] also reported similar cutoff values between in-house and manufacturer, while Chung et al. [21] found lower cutoffs for aCL IgG (13.5 $\mathrm{U} / \mathrm{mL})$ and $\mathrm{a} \beta_{2} \mathrm{GPI} \operatorname{IgM}(12.6 \mathrm{U} / \mathrm{mL})$. This discrepancy among the cutoff values could be due to the difference in demographics of the population samples evaluated by the laboratory and those of reference population evaluated by the manufacturer. This inconstant variation is an indication that a reestablishment of reference range is necessary [6]. In addition, local cutoffs should be validated through a clinical approach whenever feasible [5].

The agreements between AcuStar and ELISA results were generally good. Total agreement varied between 82.6\% and $95.7 \%$ and kappa values showed moderate to good agreement, regardless of the manufacturer' $\mathrm{s}$ or in-house cutoffs. Our findings are in accordance with the results of other studies that investigated the chemiluminescence assays $\lceil 11,12,18,21]$. In contrast to our studies, Gutensohn et al. [19] utilized five different immunoassays to detect aCL and $a \beta_{2}$ GPI IgG/IgM in SLE patients. In their study, a poor to moderate accordance was reported. This discordance was explained as differences between the antibodies used by the manufacture as well as the differences in patient groups selected, resulting in a difference of cutoff values. In our study, the overall agreement between AcuStar and ELISA was better for aCL and ${ }_{2} \beta_{2}$ GPI IgG than for IgM. Also both aCL and $a \beta_{2}$ GPI showed better correlation for IgG than for IgM. From the literature, IgM antibodies are known to be less often associated with thrombosis than IgG, and clinical utility is higher for IgG isotype $[5,6,9,17,23]$. The current classification criteria require IgG as well as IgM isotype testing for both aCL and $\mathrm{a} \beta_{2} \mathrm{GPI}$, although there is an ongoing debate about the value of IgM aPL. It is also possible that IgM rheumatoid factor (RF) has contributed to false positivity for IgM isotype aCL and $a \beta_{2} \mathrm{GPI}$ results. Thus, we need to address IgM RF interference when interpreting IgM aPL results.

In conclusion, these data suggest that the new AcuStar chemiluminescence assay shows good performance features. The automation can improve the reproducibility allowing for reduction in interlaboratory variation. We are now planning future studies to determine the clinical significance of aPL.

\section{ACKNOWLEDGEMENTS}

We are very grateful for the important technical contribution of Juhee Shin. This work was supported by 


\section{Journal of LABORATORY MEDICINE and QUALITY ASSURANCE}

Shuhua Li et al $\bullet$ Automated Antiphospholipid Antibody Test

the Dong-A University research fund.

\section{REFERENCES}

1. Lim W. Antiphospholipid syndrome. Hematology Am Soc Hematol Educ Program 2013;2013:675-80.

2. Galli M. Phospholipid inhibitors: state of the art. Hamostaseologie 2011;31:243-50.

3. Nichols WL, Kottke-Marchant K, Ledford-Kraemer MR, Homburger HA, Cardel LK. Lupus anticoagulants, antiphospholipid antibodies, and antiphospholipid syndrome. In: Kottke-Marchant K, Davis BH, editors. Laboratory hematology practice. Hoboken (NJ): WileyBlackwell, 2012:509-25.

4. Miyakis S, Lockshin MD, Atsumi T, Branch DW, Brey $\mathrm{RL}$, Cervera $\mathrm{R}$, et al. International consensus statement on an update of the classification criteria for definite antiphospholipid syndrome (APS). J Thromb Haemost 2006;4:295-306.

5. Favaloro EJ, Wong RC. Antiphospholipid antibody testing for the antiphospholipid syndrome: a comprehensive practical review including a synopsis of challenges and recent guidelines. Pathology 2014;46:481-95.

6. Lakos G, Favaloro EJ, Harris EN, Meroni PL, Tincani $\mathrm{A}$, Wong RC, et al. International consensus guidelines on anticardiolipin and anti- $\beta 2$-glycoprotein I testing: report from the 13th International Congress on Antiphospholipid Antibodies. Arthritis Rheum 2012;64:1-10.

7. Favaloro EJ. Variability and diagnostic utility of antiphospholipid antibodies including lupus anticoagulants. Int J Lab Hematol 2013;35:269-74.

8. Devreese KM, Pierangeli SS, de Laat B, Tripodi A, Atsumi T, Ortel TL, et al. Testing for antiphospholipid antibodies with solid phase assays: guidance from the SSC of the ISTH. J Thromb Haemost 2014;12:792-5.

9. Devreese KM. Antiphospholipid antibody testing and standardization. Int J Lab Hematol 2014;36:352-63.

10. Gardiner C, Hills J, Machin SJ, Cohen H. Diagnosis of antiphospholipid syndrome in routine clinical practice. Lupus 2013;22:18-25.

11. DE Moerloose P, Reber G, Musial J, Arnout J. Analytical and clinical performance of a new, automated assay panel for the diagnosis of antiphospholipid syndrome. J Thromb Haemost 2010;8:1540-6.

12. Persijn L, Decavele AS, Schouwers S, Devreese K. Evaluation of a new set of automated chemiluminescense assays for anticardiolipin and anti-beta2-glycoprotein I antibodies in the laboratory diagnosis of the antiphospholipid syndrome. Thromb Res 2011;128:565-9.

13. Clinical and Laboratory Standards Institute. Evaluation of precision performance of quantitative measurement methods: approved guideline. EP5-A2. Wayne (PA): Clinical and Laboratory Standards Institute, 2004.

14. Clinical and Laboratory Standards Institute. Evaluation of the linearity of quantitative measurement procedure: a statistical approach: approved guideline. EP06-A. Wayne (PA): Clinical and Laboratory Standards Institute, 2003.

15. Clinical and Laboratory Standards Institute. Defining, establishing, and verifying reference intervals in the clinical laboratory: approved guideline. 3rd ed. EP28A3c. Wayne (PA): Clinical and Laboratory Standards Institute, 2008.

16. Clinical and Laboratory Standards Institute. Method comparison and bias estimation using patient samples: approved guideline. 2nd ed. EP09-A2. Wayne (PA): Clinical and Laboratory Standards Institute, 2010.

17. Krilis SA, Giannakopoulos B. Laboratory methods to detect antiphospholipid antibodies. Hematology Am Soc Hematol Educ Program 2014;2014:321-8.

18. Van Hoecke F, Persijn L, Decavele AS, Devreese K. Performance of two new, automated chemiluminescence assay panels for anticardiolipin and anti-beta2glycoprotein I antibodies in the laboratory diagnosis of the antiphospholipid syndrome. Int J Lab Hematol 2012;34:630-40.

19. Gutensohn K, Vossen D, Strate A, Kersten JF, Hofbauer M, Krieger T. Automated, semi-automated, and manual analyses of anti-cardiolipin and anti- $\beta 2$-glycoprotein I antibodies in women with a history of miscarriage. Int $J$ Lab Hematol 2013;35:150-62.

20. Devreese KM, Van Hoecke F. Anticardiolipin and anti$\beta 2$ glycoprotein-I antibody cut-off values in the diagnosis of antiphospholipid syndrome: more than calculating the 


\section{Journal of LABORATORY MEDICINE and QUALITY ASSURANCE}

Shuhua Li et al • Automated Antiphospholipid Antibody Test

in-house 99th percentiles, even for new automated assays. Thromb Res 2011;128:598-600.

21. Chung Y, Kim JE, Lim HS, Kim HK. Clinical performance of anticardiolipin and anti $\beta 2$ glycoprotein I antibodies using a new automated chemiluminescent assay: superior thrombotic prediction of combined results measured by two different methods. Blood Coagul Fibrinolysis 2014;25:10-5.
22. Capozzi A, Lococo E, Grasso M, Longo A, Garofalo T, Misasi R, et al. Detection of antiphospholipid antibodies by automated chemiluminescence assay. J Immunol Methods 2012;379:48-52.

23. Pengo V, Ruffatti A, Del Ross T, Tonello M, Cuffaro S, Hoxha A, et al. Confirmation of initial antiphospholipid antibody positivity depends on the antiphospholipid antibody profile. J Thromb Haemost 2013;11:1527-31.

\section{항인지질항체 측정을 위한 자동화학발광 검사법의 수행능 평가 이주화 • 최재림 - 김보람 - 강철수 • 고리영 - 우광숙 - 한진영 동아대학교병원 진단검사의학과}

배경: 항인지질항체의 측정은 검사법과 시약의 감수성의 차이, 높은 위양성 및 위음성률, 그리고 표준 화의 부족 등과 같은 문제점이 있다. 자동화 장비를 사용하면 재현성을 높이고, 검사실 간 오차를 줄 일 수 있을 것이다. 본 연구에서는 최근 국내 도입된 ACL AcuStar 화학발광검사장비의 수행능을 평 가하고, 항인지질항체 결과를 QUANTA Lite ELISA 분석과 비교하였다.

방법: 정밀도, 직선성 및 잔재효과를 평가하였다. 135 명의 대조군 검체를 사용하여 항카디오리핀 (anticardiolipin, $\mathrm{aCL}$ )과 항베타2당단백I (anti- $\beta_{2}$ glycoprotein-I, $a \beta_{2} \mathrm{GPI}$ ) lgG 및 lgM 항체의 참 고치를 설정하였다. 또한 69 명의 환자 검체에서 얻은 네 가지 항인지질항체 검사결과를 AcuStar와 ELISA 검사법 사이에 비교하였다.

결과: AcuStar 검사는 네 가지 검사에 대해 모두 매우 우수한 정밀도, 직선성 및 잔재효과를 나타내 었다. 참고치는 각각 $\mathrm{aCL} \operatorname{lgG} 20.3 \mathrm{U} / \mathrm{mL}, \mathrm{aCL} \operatorname{lgM} 20.3 \mathrm{U} / \mathrm{mL}, \mathrm{a}_{2} \mathrm{GPI} \operatorname{lgG} 26.3 \mathrm{U} / \mathrm{mL}$, 그리 고 $\mathrm{a} \beta_{2} \mathrm{GPI} \operatorname{lgM}$ 은 $11.9 \mathrm{U} / \mathrm{mL}$ 이었다. AcuStar와 ELISA 사이의 일치율은 전반적으로 우수하였으며, 총 일치율은 $82.6 \%$ 에서 $95.7 \%$ 였고, 카파값은 중등도 내지 우수한 일치율을 보였다.

결론: 새로 도입된 AcuStar 화학발광검사는 우수한 수행평가 결과를 나타내었다. 자동화검사의 도입 으로 재현성을 높이고, 검사실 간 오차도 줄일 수 있을 것이다.

(J Lab Med Qual Assur 2015;37:134-140) 